\title{
Analisis dan Perancangan Sistem Informasi Kasir Pada Restoran The Tempoa Jelutung Jambi
}

\author{
$\underline{\text { Despita Meisak }}$ \\ Sistem Informasi, Fakultas Ilmu Komputer,Universitas Dinamika Bangsa \\ Jl Jendral Sudirman Thehok Jambi, Indonesia \\ Despitam8@gmail.com
}

\begin{abstract}
Tempoa Restaurant which is located at Jelutung Jambi, established since 2010. Currently, the restaurant still uses manual note that causes miss-calculation, untidy hadwriting and difficulty to organize the manual notes, especially at crowded situation which sometimes customers should wait in long queue to pay the bill. For better performance, there should be computerbased system to improve performance and service especially at cahshier, in which serve customer payment transaction. This research begans with problem identification, studying related literature as well as collecting data for the importance of analyzing the system requirement. The system is modeled with use case diagrams, activity diagrams and class diagrams and prototypes of software in design with Visual Basic 6.0. This study produces a cashier information system to help cashiers in order to process customer transactions effectively and efficiently, minimize customer order data input errors and facilitate the preparation of sales reports.
\end{abstract}

Keywords: cashier, information system, payment transaction, uml

\begin{abstract}
Abstrak
Restoran Tempoa Jelutung Jambi telah berdiri sejak tahun 2010. Saat ini, restoran masih menggunakan nota manual sehingga sering terjadi kesalahan kalkulasi, tulisan tangan tidak rapi, dan kesulitan untuk menata tagihan manual tersebut, khususnya pada saat pengunjung ramai sehingga membuat pelanggan harus menunggu lama untuk transaksi pembayarannya, Untuk meningkatkan performa, diperlukan sebuah sistem berbasis komputer untuk meningkatkan kinerja karyawan dan pelayanan jasa terutama kasir yang melayani transaksi pembayaran pelanggan. Penelitian ini diawali dengan identifikasi permasalahan, mempelajari literatur penelitian sejenis yang sesuai dengan permasalahan yang terkait di restoran ini, serta mengumpulkan data guna menganalisa kebutuhan sistem. Sistem dimodelkan dengan use case diagram, activity diagram dan class diagram dan prototype perangkat lunak dengan alat bantu visual basic 6.0, sehingga menghasilkan sistem informasi kasir untuk membantu kasir agar dapat memproses transaksi pelanggan dengan efektif dan efisien, meminimalisir kesalahan input data pesanan pelanggan serta mempermudah dalam penyiapan laporan penjualan.
\end{abstract}

Kata kunci : kasir, sistem informasi, transaksi pembayaran, uml

\section{Pendahuluan}

Komputer merupakan sekumpulan alat elektronik yang saling bekerja sama terkordinasi dibawah kontrol program dengan kemampuan dapat menerima data (input) lalu mengolah data (proses) tersebut sehingga menghasilkan informasi (output). Seiring berkembangnya teknologi dari waktu ke waktu, komputer memiliki peranan yang penting dalam kehidupan manusia seperti dapat menjadi multimedia hiburan yang lengkap maupun dapat membantu menyelesaikan pekerjaan dengan menghasilkan informasi yang bermanfaat baik untuk manajemen perusahaan maupun untuk kepentingan individu.

Para pelaku usaha, baik skala kecil, menengah, maupun besar sangat membutuhkan informasi yang mendukung bidang usahanya. Melalui berbagai cara, seperti survei, promosi, iklan dan kegiatan lainnya, mereka mengumpulkan informasi guna diolah, yang pada akhirnya mendapatkan kesimpulan untuk memutuskan strategi apa yang akan digunakan dalam usahanya. Dengan menggunakan bantuan sistem informasi komputer, seorang pelaku usaha dapat dengan cepat dan mudah mengumpulkan dan menganalisa informasi yang ada, sehingga dihasilkan keputusan yang tepat [1], studi jaringan pelengkap perangkat keras dan perangkat lunak yang digunakan orang dan organisasi untuk mengumpulkan, 
memfilter, memproses, membuat, dan mendistribusikan data [2], sekumpulan komponen yang bekerja sama untuk mengumpulkan, mengolah, menyimpan, dan menyebarluaskan informasi untuk mendukung pengambilan keputusan, koordinasi, pengawasan, analisis, dan visualisasi dalam suatu organisasi [3].

Sistem informasi kasir mempermudah perhitungan dalam proses transaksi yang dilakukan bisa meminimalisir waktu perhitungan, meminimalisir kesalahan yang terjadi dan pembuatan struk atau nota pembayaran [4] dan mempermudah para stakeholder dalam melakukan proses pemesanan baik itu berupa makanan dan minuman, memperkecil kesalahan yang diakibatkan oleh human error seperti salah memasukkan nomor meja, mengurangi kesalahan dalam proses pembayaran, membantu pemilik dalam melihat laporan [5]. sehinga dapat mempercepat proses penjualan serta meningkatkan penjualan yang ada [6].

Restoran The Tempoa Jelutung Jambi merupakan sebuah tempat makan di jambi sudah berdiri sejak tahun 2010 kini menjalin kerjasama dengan sekolah GHS (Gentala Hospitality School).Melayani pemesanan makanan untuk acara gathering, meeting, ulang tahun, buka puasa dan lain-lain. Semakin meningkatnya pengunjung membuat Restoran The Tempoa Jelutung Jambi mengalami beberapa kesulitan dalam transaksi pembayaran karna masih menggunakan nota manual untuk pembayaran transaksinya seperti kesalahan memberi harga, kalkulasi, tulisan yang kurang jelas, banyak arsip manual/bill yang tidak tersusun rapi pada saat restoran ramai pengunjung, karena nota di isi dengan manual, membuat konsumen mengantri lama untuk membayar dan hanya satu kasir yang melayani mempengaruhi kenyamanan kosumen, dan laporan yang dihasilkan tidak lengkap sehingga manajer kesulitan melakukan evaluasi kinerja restoran maka diperlukan suatu sistem informasi guna membantu kinerja restoran. Dari permasalahan tersebut maka penelitian ini bertujuan untuk merancang suatu sistem informasi kasir restoran The Tempoa Jelutung Jambi.

\section{Metodologi}

Pada penelitian ini dilakukan langkah-langkah berikut ini :

a. Identifikasi Masalah untuk mencari solusi serta peluang atas permasalahan yang ada

b. Studi Literatur, yaitu mempelajari dan memahami teori-teori yang menjadi panduan dan referensi untuk penyelesaian masalah terkait dan mempelajari penelitian yang relevan dengan masalah yang terkait.

c. Pengumpulan data terkait penelitian yang penulis lakukan dengan melakukan observasi dan wawancara langsung dengan pihak terkait.

d. Melakukan analisa kebutuhan system, menguraikan dari suatu sistem informasi yang utuh ke dalam bagian-bagian komponennya dengan maksud untuk mengidentifikasi dan mengevaluasi permasalahan-permasalahan, kesempatan-kesempatan, hambatan-hambatan yang terjadi dan kebutuhan-kebutuhan yang diharapkan sehingga dapat diusulkan perbaikan-perbaikannya [7].

e. Membuat pemodelan sistem menggunakan Use Case Diagram, Activity Diagram, dan Class Diagram, UML (Unifies Modelling Langguage) adalah sebuah "Bahasa" yang telah menjadi standar dalam industri untuk masalah visualisasi, merancang dan mendokumentasikan sistem piranti lunak [8].

f. Merancang user interface dengan Wireframe Prototype untuk membangun sistem informasi kasir yaitu dengan menggunakan tool Visual Basic 6.0

\section{Hasil dan Pembahasan}

\subsection{Analisis Kebutuhan Sistem}

Berdasarkan observasi yang penulis lakukan pada restoran the tempoa jelutung jambi maka dapat di identifikasi permasalahan yang ada, yaitu dibutuhkan suatu sistem informasi kasir yang dapat membantu kasir dalam meminimalisir kesalahan transaksi pelanggan, sehingga kinerja kasir dapat menjadi lebih efektif dan efisien dalam menangani transaksi pelanggan. Membantu pihak pengelola resto dalam meng evaluasi kinerja resto dapat dilihat dari laporan penjualan yang di hasilkan oleh sistem.

Pemodelan fungsional sistem menggambarkan proses atau fungsi yang harus dikerjakan oleh sistem dalam melayani kebutuhan pengguna (user). Pada penjabaran di atas ada 2 pengguna dalam sistem 
informasi kasir, yaitu: kasir dan pengelola, maka ada beberapa fungsi yang harus dilakukan oleh sistem informasi kasir restoran The Tempoa Jelutung Jambi yaitu:

a. Fungsi Login: Fungsi ini digunakan oleh kasir dan pengelola untuk login dengan menggunakan Username dan Password sebelum mengakses sistem informasi kasir Restoran The Tempoa Jelutun Jambi

b. Fungsi Kategori Makanan dan Minuman: Fungsi ini digunakan untuk menambah, mengubah, menghapus data kategori makanan dan minuman yang ada pada sistem

c. Fungsi Menu Makanan: Fungsi ini digunakan untuk menambah, mengubah, menghapus data menu makanan dan harga makanan yang ada pada sistem

d. Fungsi Menu Minuman : Fungsi ini digunakan untuk menambah, mengubah, menghapus data menu minuman dan harga minuman yang ada pada sistem

e. Fungsi Menu Admin : Fungsi ini digunakan untuk menambah, mengubah, menghapus data admin/user yang akan menggunakan sistem

f. Fungsi Master Meja : Fungsi ini digunakan untuk menambah, mengubah, menghapus data Meja yang ada di restoran

g. Fungsi Orderan Dine In, Take away dan Gathering : Fungsi ini digunakan untuk menginput data transaksi orderan pelanggan yang makan di restoran (Dine In), Seminar/Rombongan (gathering) dan pelanggan yang bungkus (Take Away) pada sistem

h. Fungsi Pindah Meja : Fungsi ini digunakan unruk memindahkan no meja pelanggan yang ada pada sistem

i. Fungsi Join Meja : Fungsi ini digunakan untuk menggabungan beberapa no meja pelanggan ke dalam satu bill transaksi yang ada pada sistem

j. Fungsi Cetak Orderan : Fungsi ini digunakan untuk mencetak orderan pelanggan untuk di serahkan ke kitchen/ bagian dapur untuk dipersiapkan orderan makanan dan minuman nya,

k. Fungsi Cetak Bill : Fungsi ini digunakan untuk mencetak bill transaksi pelanggan sebelum dilakukan transaksi pembayaran pada sistem

1. Fungsi Cetak pembayaran : Fungsi ini digunakan untuk mencetak transaksi pembayaran orderan pelanggan pada sistem

m. Fungsi Cetak laporan: Fungsi ini digunakan untuk mencetak laporan penjualan restoran the tempoa jelutung jambi pada sistem

n. Fungsi Log Out: Fungsi ini digunakan untuk user keluar dari sistem

Use Case adalah rangkaian sekelompok yang saling terkait dan membentuk system secara teratur yang dilakukan atau diawasi oleh sebuah aktor [9]. Pada Diagram Use case, kita dapat menggambarkan peran atau fungsi apa yang dilakukan oleh pihak luar terhadap sistem, untuk mencapai tujuan tertentu [10]. Use case diagram digunakan untuk memodelkan fungsional sistem yang digunakan dari sudut pandang user. Maka dapat digambarkan diagram Use case pada sistem informasi sistem informasi kasir pada restoran The Tempoa Jelutung Jambi sebagai berikut :

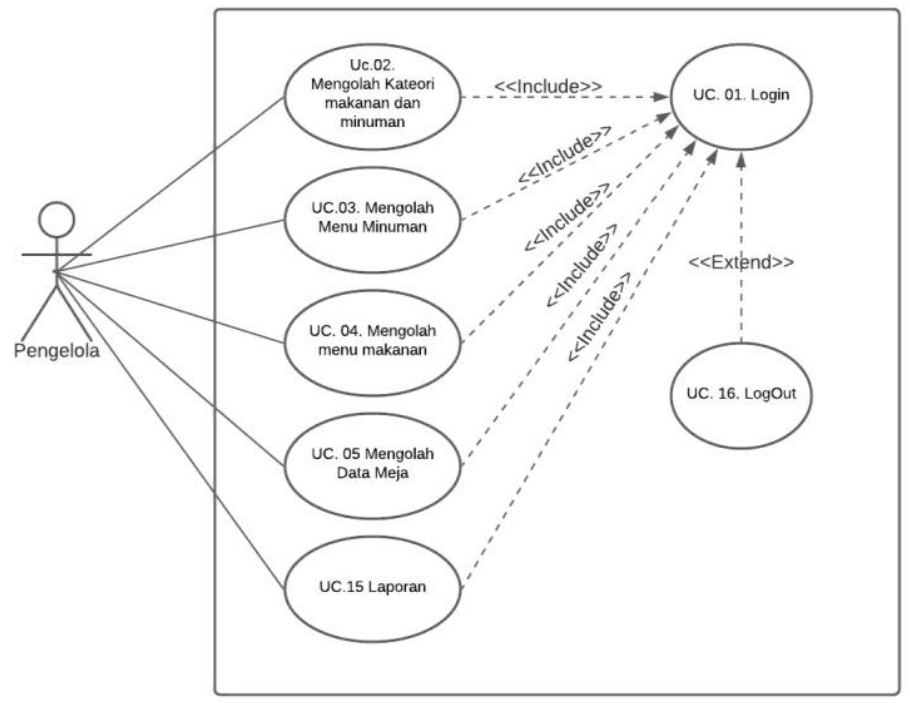

Gambar 1. Use Case Diagram Pengelola 


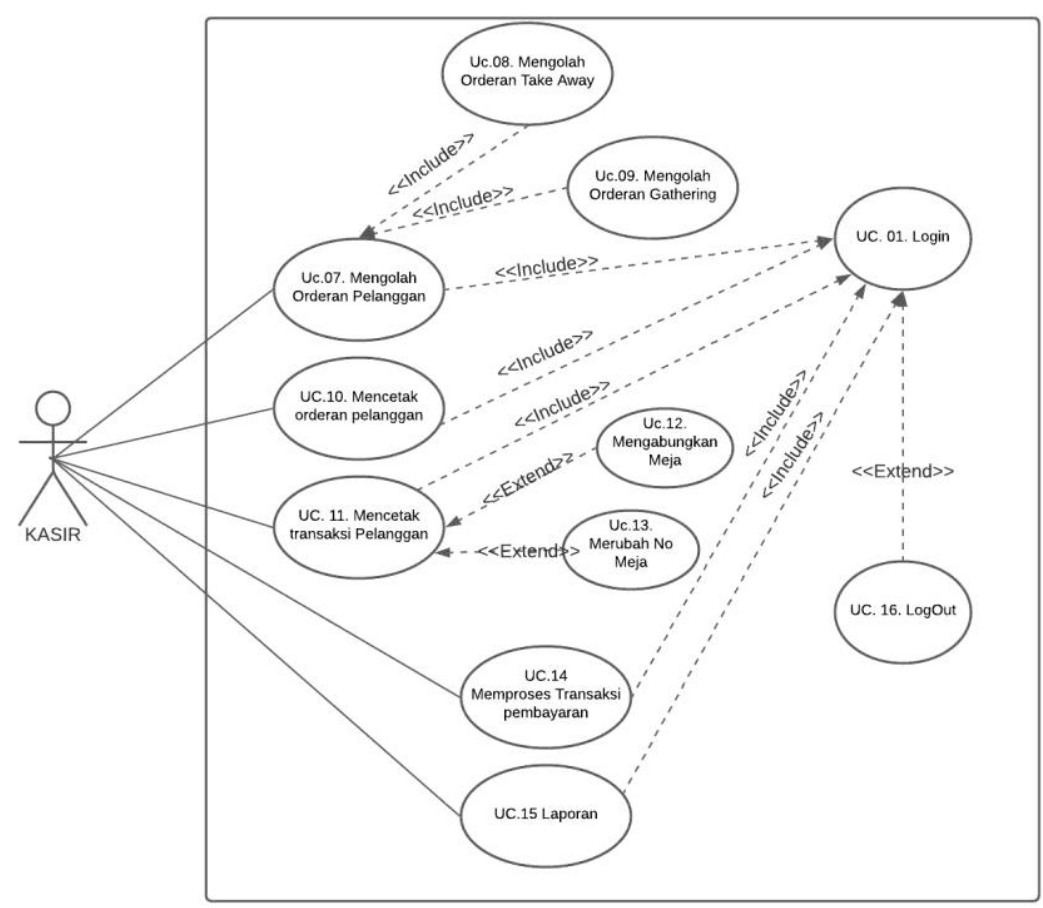

Gambar 2. Use Case Diagram Kasir

\subsubsection{Class Diagram}

Class diagram menggambarkan struktur dan deskripsi class, package dan objek serta hubungan satu sama lain seperti inheritance, association dan lain-lain [8]. Kebutuhan data untuk perangkat lunak yang akan dibuat dapat digambarkan dengan class diagram yang merupakan hubungan antar class yang saling terkait.

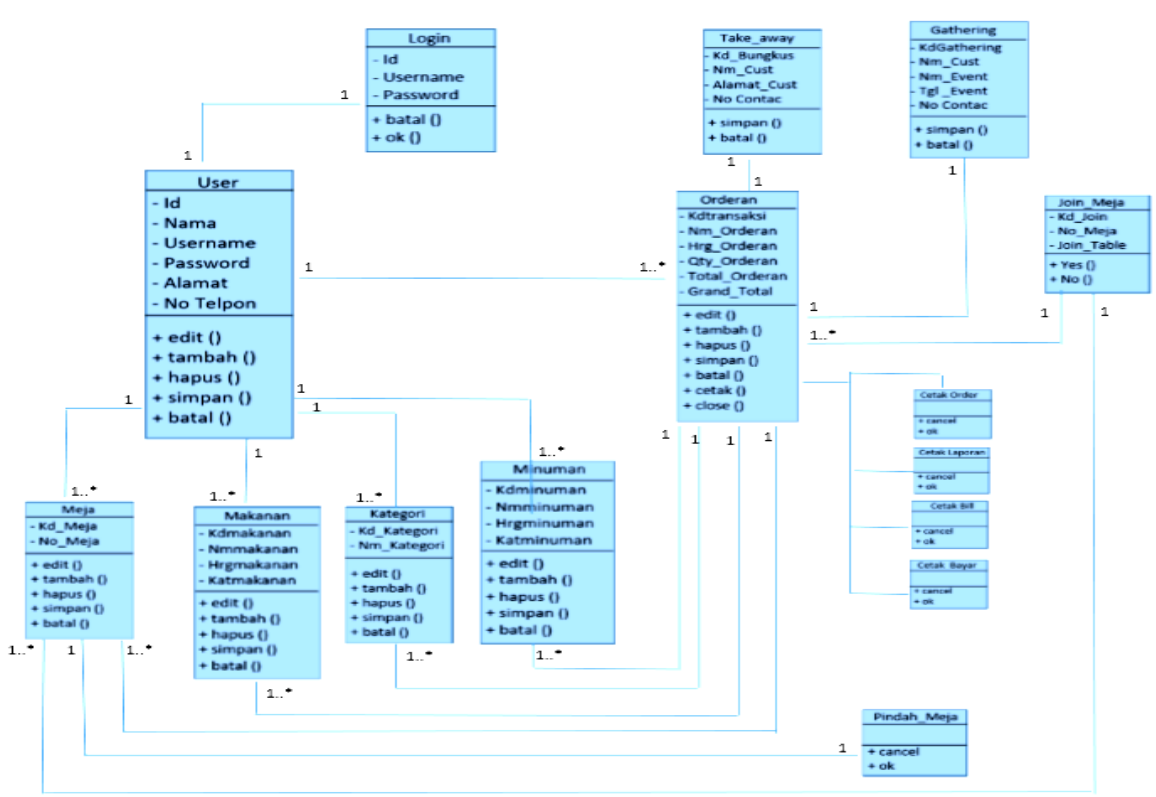

Gambar 3. Class Diagram 


\subsubsection{Prototype Sistem}

Prototype adalah suatu versi sistem pontensial yang disediakan bagi pengembang dan calon pengguna yang dapat memberikan gambaran bagaimana kira-kira sistem tersebut akan berfungsi bila telah disusun dalam bentuk yang lengkap. Adapun tampilan prototype sistem informasi kasir pada restoran the tempoa jelutung jambi adalah sebagai berikut :

1. Tampilan Halaman Menu Utama

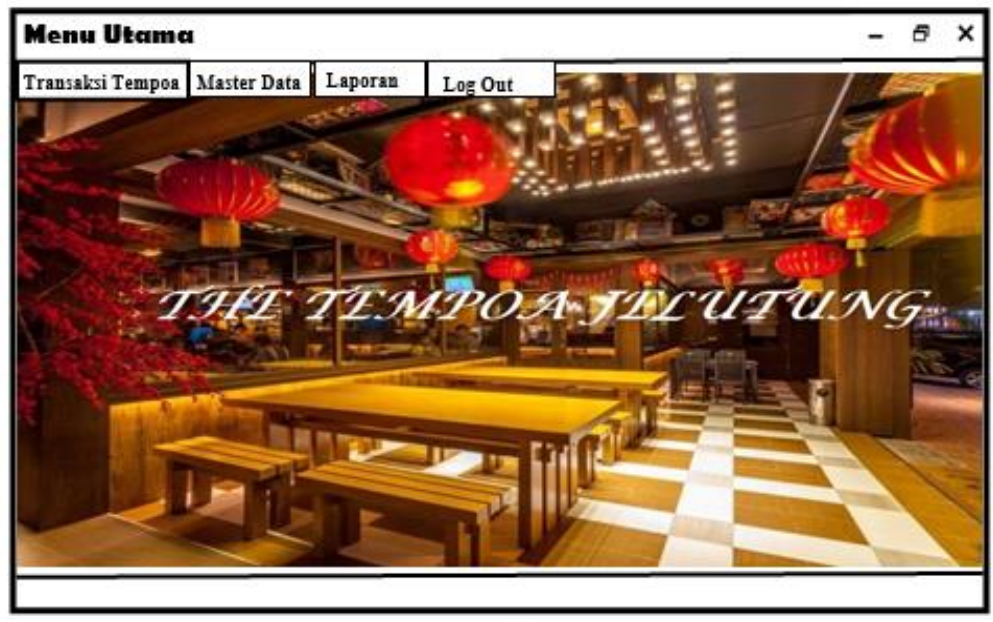

Gambar 4. Tampilan Hälaman Menu Utama

Gambar diatas adalah tampilan halaman utama untuk kasir dan pengelola memproses transaksi pelanggan, input master data restoran, laporan penjualan dan Log Out untuk keluar dari sistem. Pengelola mengisi data Meja yang ada di restoran The Tempoa Jelutung jambi, dengan mengisi form input data Meja, jika pengelola ingin menambah data meja yaitu dengan mengklik menu tambah dan mengisi halaman input data meja lalu klik simpan, jika ingin mengedit maka dengan mengklik data meja pada master data admin kemudian klik menu edit sistem akan menampilkan halaman edit data meja dan jika actor ingin menghapus data meja maka cukup mengklik data pada master data meja kemudian klik hapus maka data secara otomatis akan terhapus pada master data meja.

2. Tampilan Halaman Transaksi Tempoa

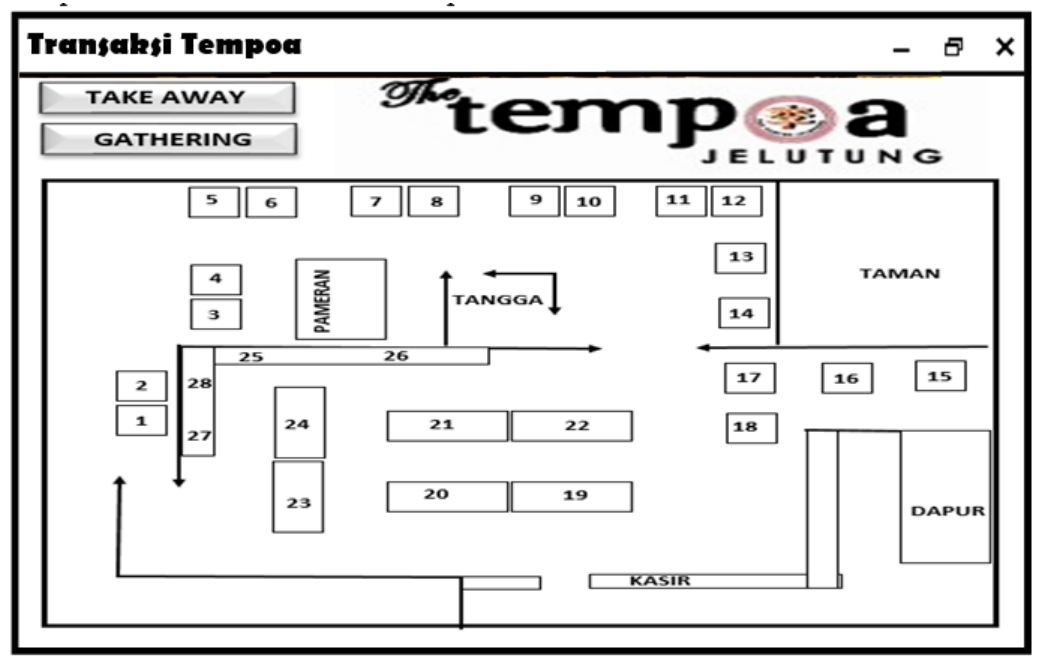

Gambar 5. Tampilan Halaman Transaksi Restoran

Gambar diatas merupakan tampilan meja restoran yang ada di restoran, ada 3 jenis transaksi pelanggan yaitu Dine in untuk pelanggan makan di restoran, Take away untuk pelanggan yang tidak 
makan di restoran, dan Gathering untuk pelanggan yang membawa tamu rombongan atau mengadakan pertemuan di restorant.

3. Tampilan Halaman Orderan Dine In

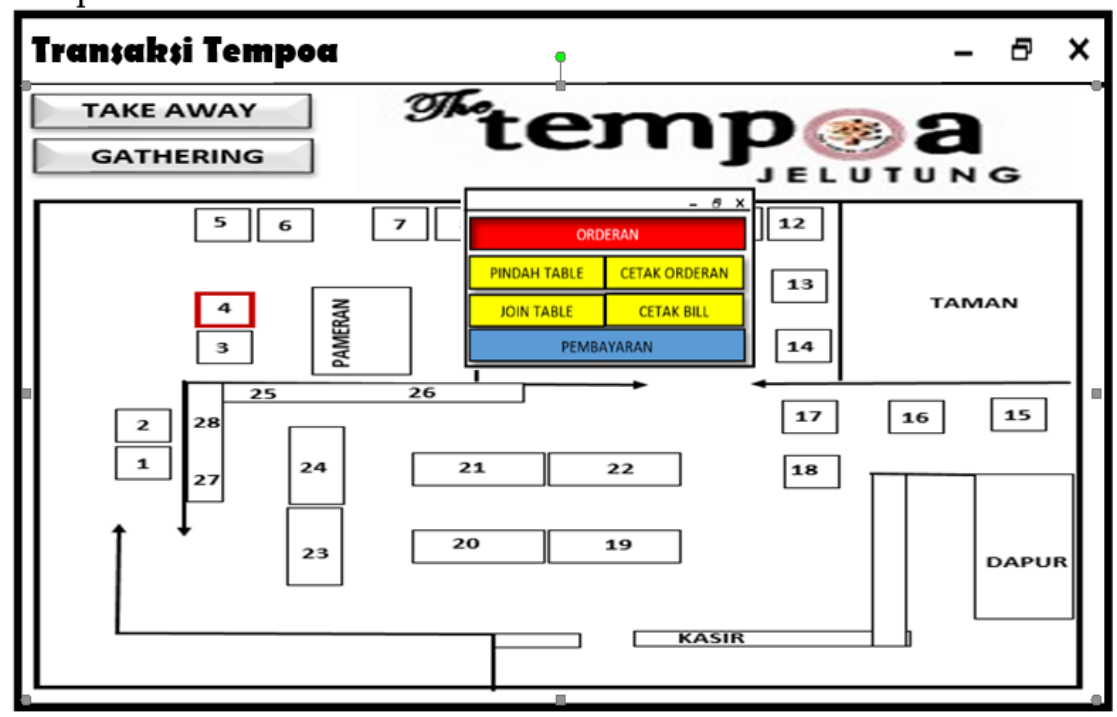

Gambar 6. Tampilan Halaman Transaksi Dine In

Gambar diatas merupakan tampilan orderan Transaksi Dine In, pada halaman ini kasir memilih no meja pelanggan, maka sistem akan menampilkan textbox orderan pelanggan, kasir mengklik "Orderan" untuk memasukan data pesanan pelanggan

4. Tampilan Halaman Input Data Orderan Dine In Kategori F N B

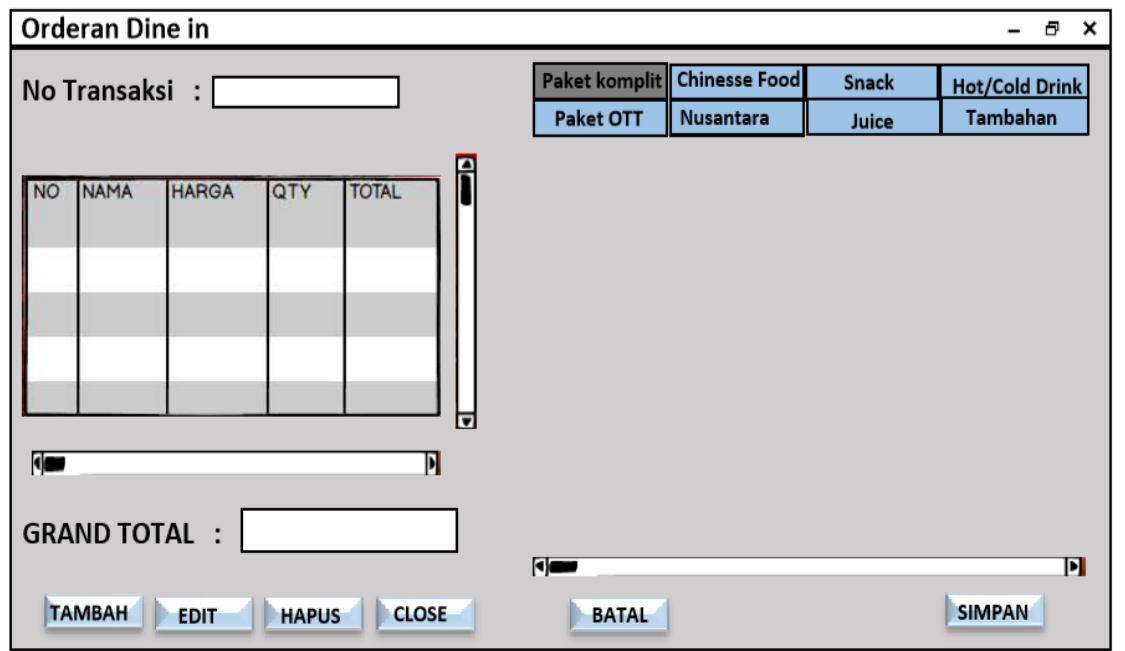

Gambar 7. Tampilan Halaman Input Orderan Restoran (Dine In) Kategori Makanan

Gambar diatas menampilkan halaman orderan pelanggan Kategori makanan dan minuman yang tersedia di restoran. Pada halaman ini kasir memilih kategori makanan dan minuman sesuai dengan pesanan pelanggan, maka sistem akan menampilkan data makanan dan minuman yang tersedia di restoran 
5. Tampilan Halaman Input Data Orderan Dine In Menu F N B

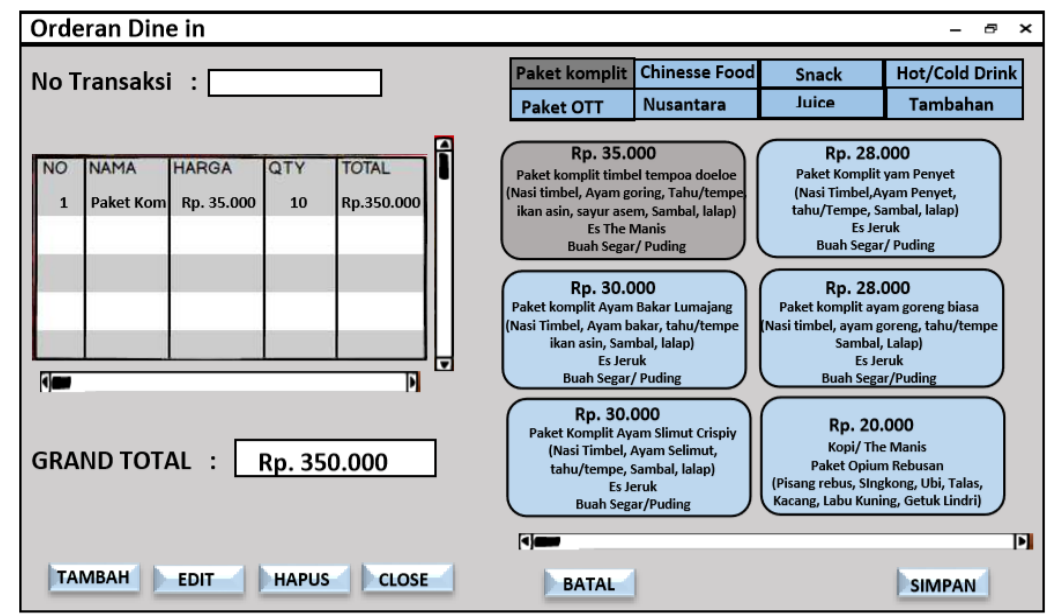

Gambar 8. Tampilan Menu Makanan Dan Minuman Restoran

Gambar diatas menampilkan halaman input orderan dine in menu makanan dan minuman yang tersedia di restoran. Pada halaman ini kasir memilih menu makanan dan minuman pesanan pelanggan dan secara otomatis data makanan dan minuman serta nominal harga terinput ke dalam tabel transaksi pelanggan.

6. Tampilan Halaman Pindah meja pelanggan

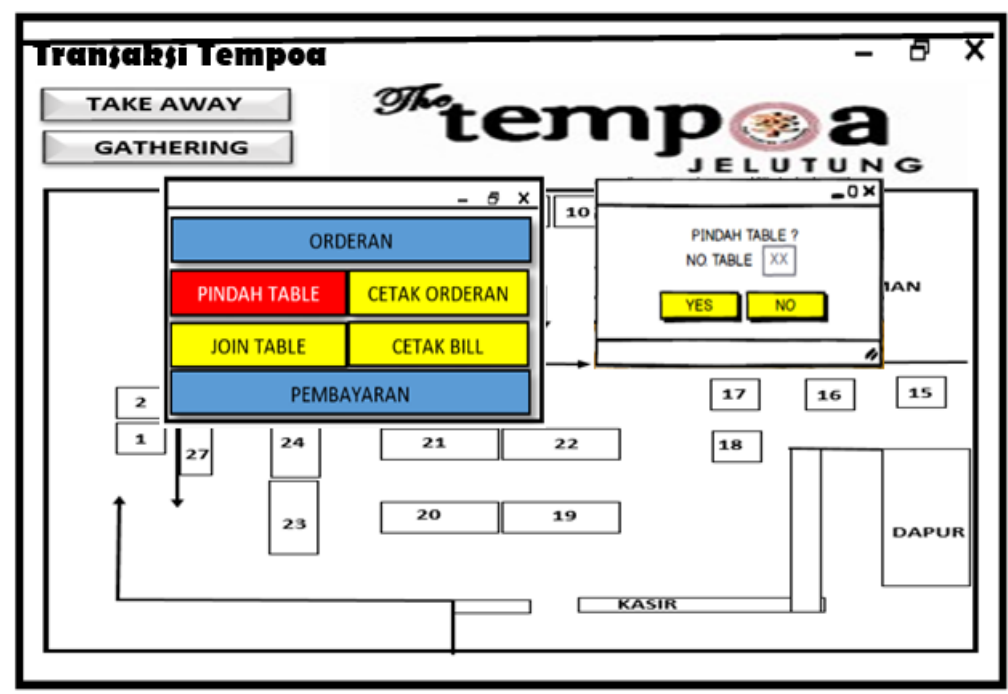

Gambar 9. Tampilan Halaman Pindah Meja Pelanggan

Gambar diatas menampilkan halaman pindah meja pelanggan, jika pelanggan ingin pindah meja ke meja yang lain, maka kasir mengklik menu Pindah Table pada sistem untuk memindah ke meja pelanggan. Dengan menrubah ni meja pelanggan sesuai dengan no meja yang di tempati pelanggan. 
7. Tampilan Halaman Gabung Meja Pelanggan

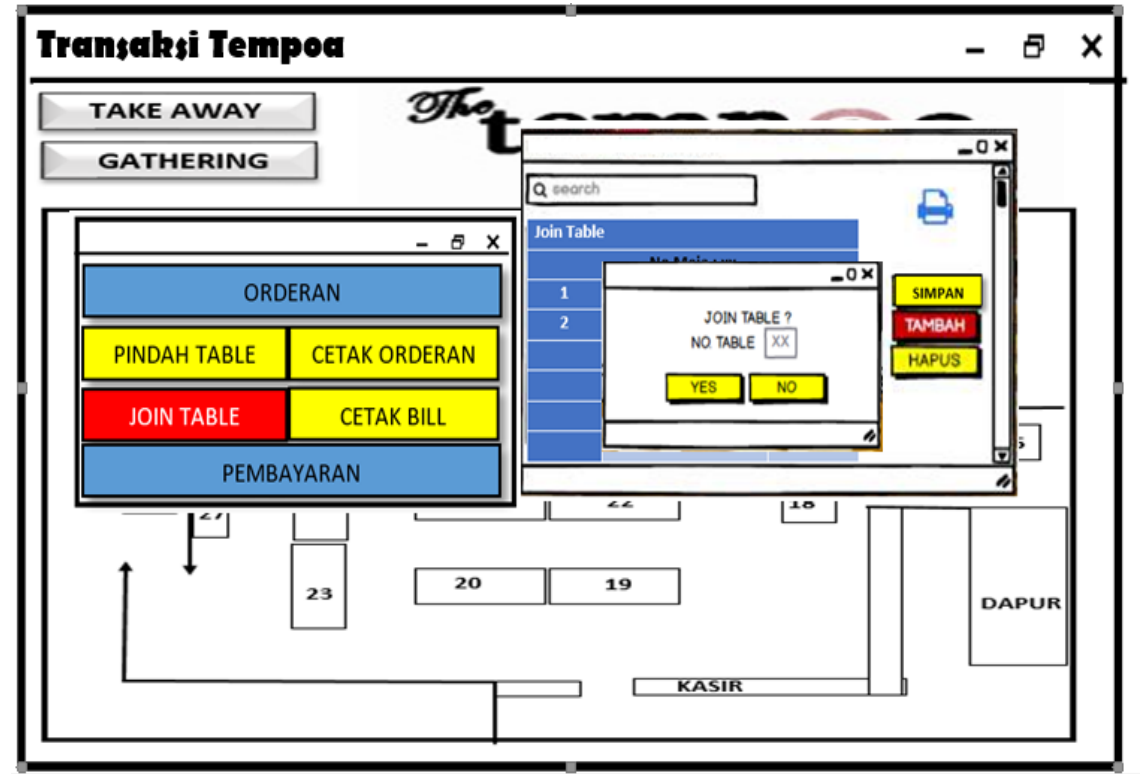

Gambar 10. Tampilan Halaman Join Meja Pelanggan

Gambar diatas menampilkan halaman Join table pelanggan, kasir menggunakan menu join table untuk menggabungkan bill pelanggan dari beberapa meja pelanggan, sesuai intruksi dari pelanggan yang ingin menggabungkan bill nya

8. Tampilan Halaman Cetak Orderan

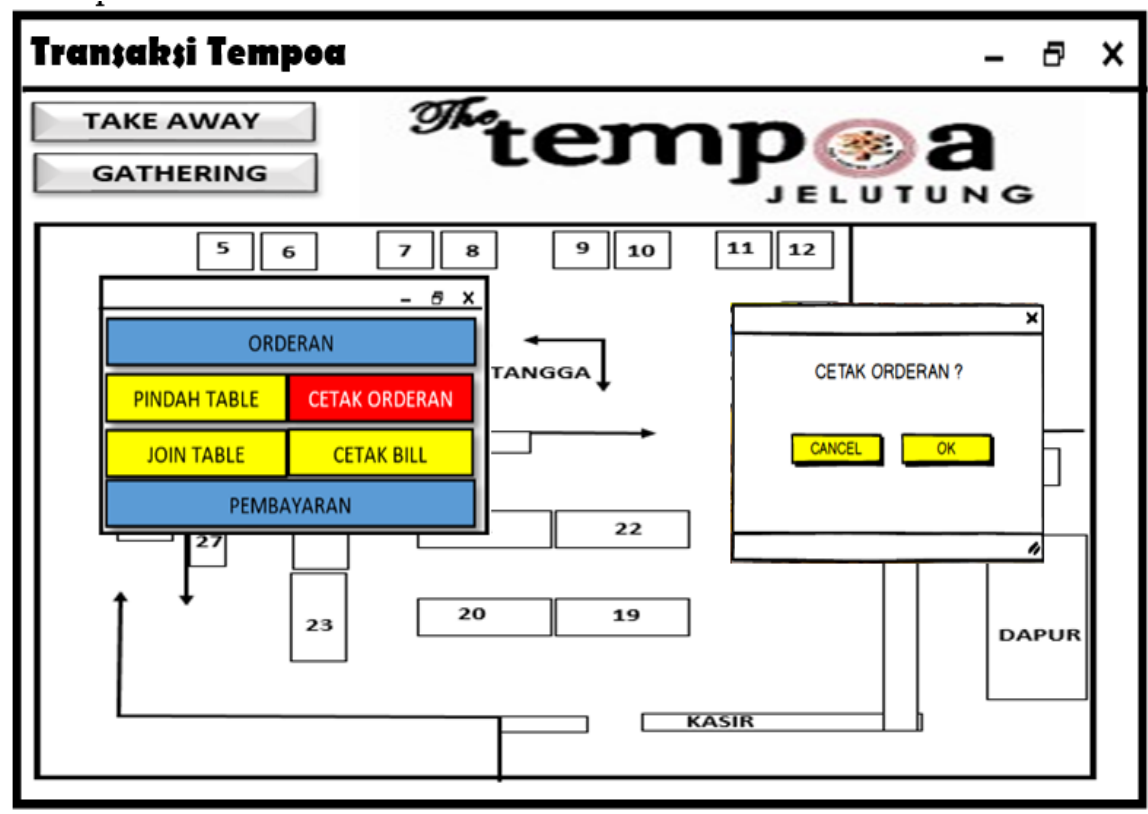

Gambar 11. Tampilan halaman Cetak Orderan Pelanggan

Kasir mencetak orderan pelanggan untuk diserahkan ke bagian dapur/kitchen untuk di siapkan orderan makanan dan minumannya berdasarkan kertas orderan dari kasir. 
9. Tampilan Halaman Cetak Bill

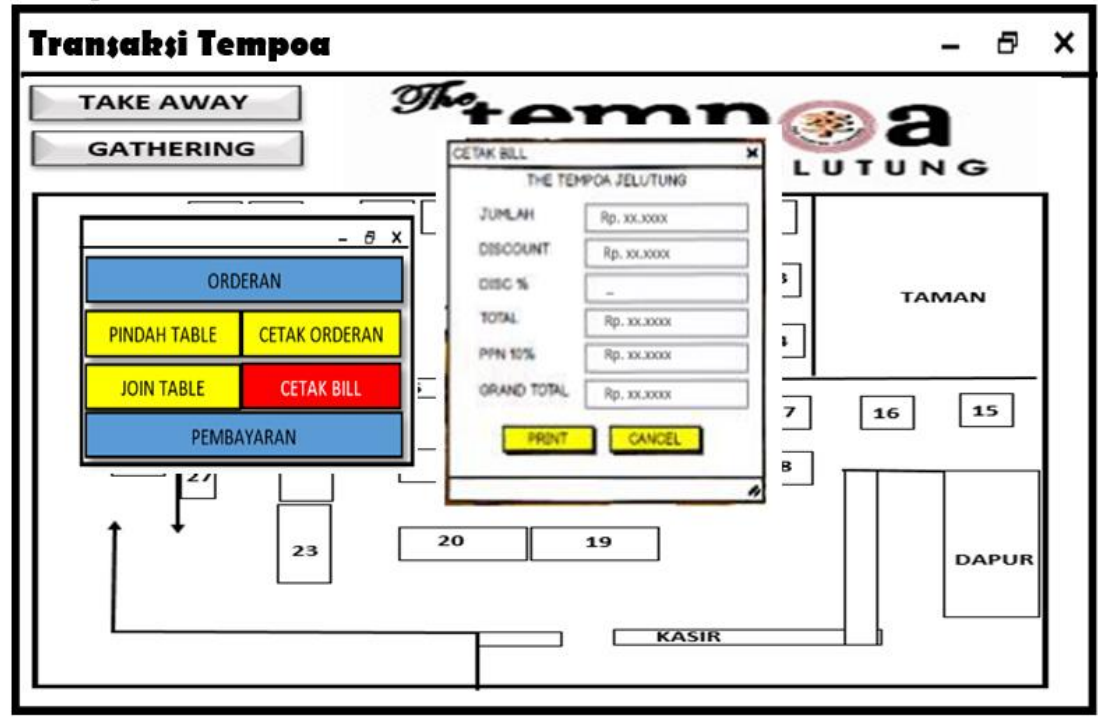

Gambar 12. Tampilan halaman Cetak Bill Pelanggan

Kasir mencetak bill pelanggan dengan mengklik menu Cetak Bill, tujuan untuk mengkonfirmasi pembayaran kepada pelanggan jika ada kesalahan dalam penginputan orderan maka masih bisa di rubah sebelum melakukan transaksi pembayaran secara tunai atau non tunai

10. Tampilan Halaman Pembayaran

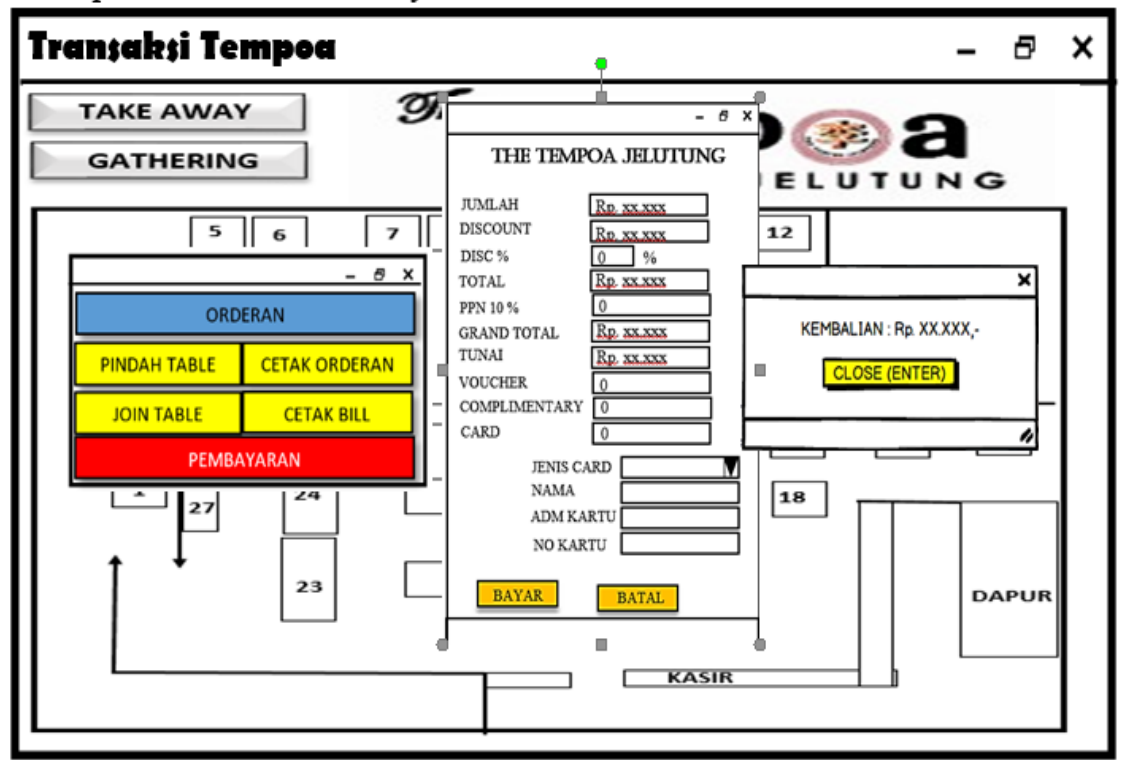

Gambar13. Tampilan halaman Cetak Bill Pelanggan

Kasir memproses transaksi pembayaran pelanggan dengan mengklik no meja pelanggan dan mengklik menu pembayaran setelah melakukan konfirmasi memastikan orderan benar sebelumnya, setelah itu kasir baru dapat memproses pembayaran pelanggan karna saat proses pembayaran telah dilakukan maka transaksi pelanggan tidak dapat di batalkan 
11. Tampilan Halaman transaksi Take Away / Bungkus
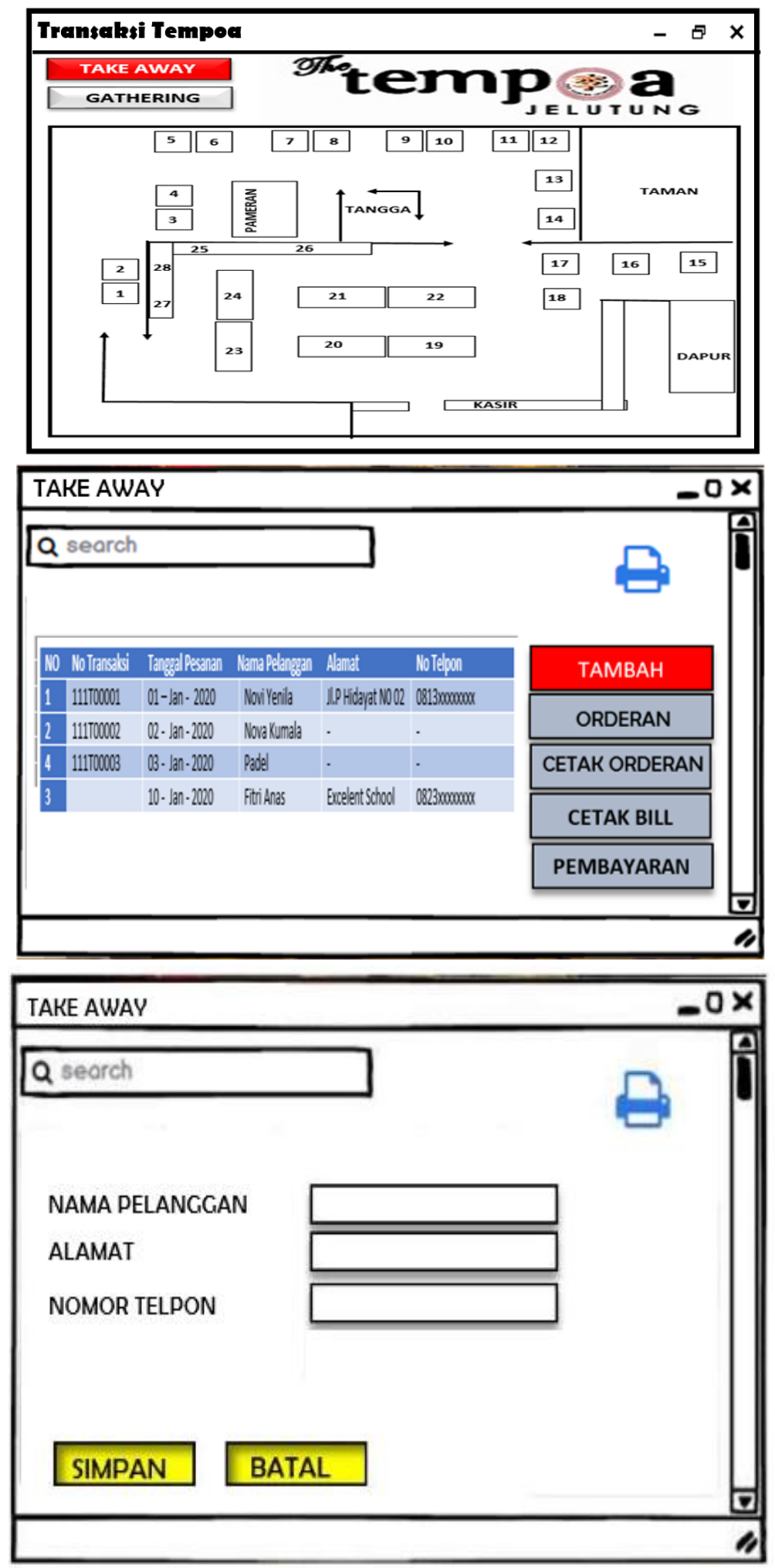

Gambar 14. Tampilan Proses Transaksi Take Away/ Bungkus

Kasir memproses transaksi orderan pelanggan take away/bungkus dengan mengklik menu take away, kemudian sistem akan menampilkan daftar/list data pelanggan yang bungkus. Kasir ingin menginput data pelanggan bungkus dengan mengklik menu tambah maka akan tampil halaman input data pelangan bungkus, kemudian kasir mengklik data pelanggan untuk diinput data orderan makanan 
dan minuman pelanggan dengan mengklik menu orderan, kemudian mengklik menu cetak orderan diserahkan ke kasir untuk disiapkan orderannya, kemudian kasir mencetak bill untuk diserahkan ke pelanggan memastikan orderan benar, jika sudah konfirmasi bill maka kasir bisa memproses transaksi pembayaran pelanggan.

12. Tampilan Halaman Transaksi Gathering
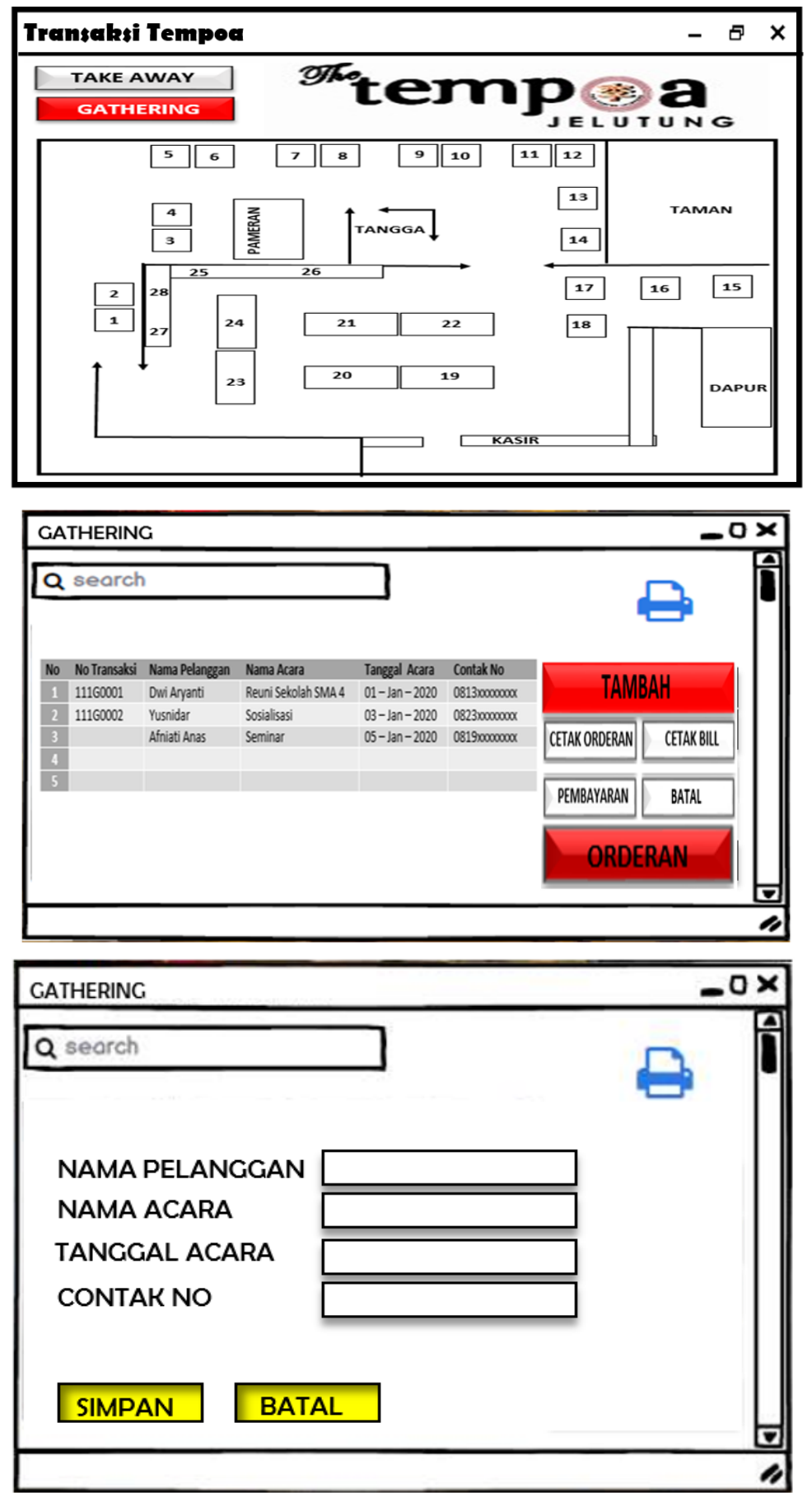

Gambar 15. Tampilan Proses Transaksi Gathering

Kasir memproses transaksi orderan pelanggan Gathering dengan mengklik menu gathering, kemudian sistem akan menampilkan daftar/list data pelanggan rombongan. Kasir ingin menginput data pelanggan rombongan dengan mengklik menu tambah maka akan tampil halaman input data pelangan, kemudian kasir mengklik data pelanggan pada list untuk diinput data orderan makanan dan 
minuman pelanggan dengan mengklik menu orderan, kemudian mengklik menu cetak orderan diserahkan ke kasir untuk disiapkan orderannya, kemudian kasir mencetak bill untuk diserahkan ke pelanggan memastikan orderan benar, jika sudah konfirmasi bill maka kasir bisa memproses transaksi pembayaran pelanggan.

13. Tampilan Laporan Penjualan

\begin{tabular}{|c|c|c|c|c|c|c|c|c|c|}
\hline close & $\underset{\mathrm{Excel}}{\mathrm{T}}$ & selup & Fing & & & & & & \\
\hline \multicolumn{3}{|l|}{ Dąte: Range } & \multirow{2}{*}{\multicolumn{2}{|c|}{ Șort by: $:$ Pelanggan }} & \multirow[t]{2}{*}{$\sim$} & \multirow[t]{2}{*}{ OK } & & & \\
\hline From: $\operatorname{Jan} 1,2020$ & $\checkmark$ To: & $\operatorname{Tan} 1,2020$ & & & & & & & \\
\hline \multicolumn{10}{|c|}{ 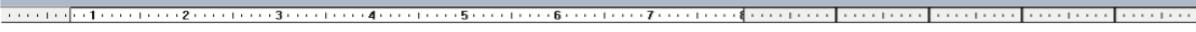 } \\
\hline \multicolumn{3}{|c|}{ TEMPOA JELUTUNG JAMBI } & \multicolumn{7}{|c|}{$\begin{array}{l}\text { Laporan : Transaksi Penjualan } \\
\text { Periode : } 01 \text { - Jan - } 2020 \text { Sampai } 01-\text { Jan }-2020\end{array}$} \\
\hline \multicolumn{10}{|c|}{ Halaman : 1 dari 1} \\
\hline NO.TRANS & DATE & PELANGGAN & KATEGORI & MENU & QTY & HARGA & TOTAL & MEJA & KASIR \\
\hline $111 D 00001$ & $01 / 01 / 2020$ & Dine In & Paket Komplit & Paket komplit timbe1 & 2 & 35.000 & 70.000 & 2 & $\mathrm{~K}-01$ \\
\hline $111 D 00002$ & $01 / 01 / 2020$ & Dine In & Chinesse Food & Seafood 3 rasa & 1 & 28.000 & 28.000 & 4 & $\mathrm{~K}-01$ \\
\hline $111 D 00002$ & $01 / 01 / 2020$ & Dine In & Chinesse Food & Sapi lada hitam & 1 & 27.000 & 27.000 & 4 & $\mathrm{~K}-01$ \\
\hline $111 D 00002$ & $01 / 01 / 2020$ & Dine In & Juice & Juice Alpukat & 2 & 17.000 & 34.000 & 4 & $\mathrm{~K}-01$ \\
\hline $111 D 00003$ & $01 / 01 / 2020$ & Dine In & Nusantara & Nasi uduk bakar & 3 & 27.000 & 81.000 & 7 & $\mathrm{~K}-01$ \\
\hline $111 D 00003$ & $01 / 01 / 2020$ & Dine In & Juice & Juice Jeruk & 3 & 17.000 & 51.000 & 7 & $\mathrm{~K}-01$ \\
\hline $111 G 00001$ & $01 / 01 / 2020$ & Gathering & Paket Komplit & Paket komplit timbel & 20 & 35.000 & 700.000 & - & $\mathrm{K}-01$ \\
\hline 111G00001 & $01 / 01 / 2020$ & Gathering & Paket OTT & Teh/bakwani, pisang, & 20 & 20.000 & 400.000 & - & $\mathrm{K}-01$ \\
\hline \multicolumn{10}{|c|}{ Grand Total } \\
\hline
\end{tabular}

Gambar 16. Tampilan Laporan penjualan restoran

Tampilan gambar di atas merupakan laporan penjualan restoran the tempoa jelutung, jika actor ingin melihat atau mencetak laporan penjualan pada range tanggal tertentu, seluruh laporan, periode, pertahun, perminggu, atau penjualan hari ini saja, actor dapat mengaturnya pada menu Date dan range tanggal nya, kemudian jika actor ingin mensortir laporan berdasarkan judul pada kolom laporan bisa dengan menu Sort By kemudian klik tombol ok.

\section{Kesimpulan}

Penelitian ini menghasilkan rancangan prototype sistem informasi kasir pada Restoran The Tempoa Jambi. Sistem yang dirancang bertujuan untuk membantu kasir agar dapat memproses transaksi pelanggan dengan efektif dan efisien karena pada proses transaksi pembayaran pelanggan terintegrasi dengan data meja, makanan, minuman dan nominal dari pesanan pelanggan sehingga membantu meminimalisir kesalahan input data pesanan pelanggan serta mempermudah penyiapan laporan penjualan restoran.

\section{Daftar Pustaka}

[1] D. Kreasi, software kasir paling mutakhir. Yogyakarta: Mediakom, 2018.

[2] D. T. Bourgeois, "Bourgeois, David T. Information systems for business and beyond." Saylor Academy., Washington, DC, 2014.

[3] G. P. McLeod, R., \& Schell, "Management information systems (Vol. 104)." Pearson/Prentice Hall., USA, 2007.

[4] A. Muthohari, Bunyamin, and S. Rahayu, "Pengembangan aplikasi kasir pada sistem informasi rumah makan padang ariung," J. Algoritm. Sekol. Tinggi Teknol. Garut, vol. 13, pp. 157-163, 2016.

[5] N. W. David, "Sistem Pemesanan Rumah Makan Xyz Berbasis Desktop," KURAWAL J. Teknol. Informasi, dan Ind., vol. I, no. 2, pp. 98-106, 2018, doi: https://doi.org/10.33479/kurawal.2018.1.2.98-106.

[6] Hendri, "Perancangan dan pengembangan sistem informasi akuntansi penjualan berbasis Web pada Marlina shop jambi," J. MEDIASISFO, vol. 10, no. 2, pp. 652-665, 2016.

[7] H. . Jogiyanto, Analisa dan design sistem informasi: pendekatan terstruktur dan praktik sistem informasi bisnis. Yogyakarta: Andi, 2005.

[8] Meilan Anastasia, Analisa dan perancangan sistem informasi dengan Codeigniter dan laravel. Yogyakarta: CV.Loko Media, 2018.

[9] Hanim, Analisis serta Perancangan Sistem Informasi melalui pendekatan UML. Yogyakarta: Andi, 2014.

[10] S. Falahah, Rekayasa Perangkat Lunak. Bandung: Lentera Ilmu Cendikiawan, 2018. 